\title{
Preparation and Characterization of Chabazite from Construction Waste and Application as an Adsorbent for Methylene Blue
}

\author{
Xue Song $\mathbb{D}$, Yingming Zhang $\left(\mathbb{D}\right.$, Xiangke Cui $\mathbb{D}^{D}$, Fangfang Liu $\mathbb{D}$, and Hailiang Zhao $\mathbb{D}$ \\ College of Environmental Engineering, Henan University of Technology, Lianhua Street 100, 450001 Zhengzhou, China \\ Correspondence should be addressed to Hailiang Zhao; hailiang.zhao@haut.edu.cn
}

Received 26 March 2021; Revised 12 May 2021; Accepted 7 June 2021; Published 25 June 2021

Academic Editor: Ming Hua

Copyright (@ 2021 Xue Song et al. This is an open access article distributed under the Creative Commons Attribution License, which permits unrestricted use, distribution, and reproduction in any medium, provided the original work is properly cited.

\begin{abstract}
Construction waste, produced from building projects, was utilized to prepare chabazite by alkali fusion hydrothermal synthesis method. The synthesized chabazite was used as an adsorbent for the removal of methylene blue (MB). XRD, FTIR, and $\mathrm{N}_{2}$ adsorption/desorption curves were adopted to describe the physical and chemical properties of the samples. The results show that the synthesized chabazite possesses crystalline structure, typical functional groups, and large specific surface area of 421.34 $\mathrm{m}^{2} \mathrm{~g}^{-1}$. Adsorption isotherms and kinetic curves show that the adsorption process follows the Langmuir model and pseudosecond-order kinetics model. The maximum adsorption capacity of MB on the synthesized chabazite reaches up to $129.18 \mathrm{mg} g$ ${ }^{1}$ at $298 \mathrm{~K}$, which is about 16 times that of construction waste. The removal rate of MB reaches more than $90 \%$, and the

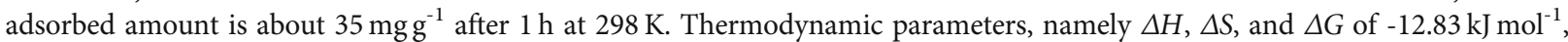
$-27.37 \mathrm{~J} \mathrm{~mol}^{-1} \mathrm{~K}^{-1}$, and $-4.68 \mathrm{~kJ} \mathrm{~mol}^{-1}$ at $298 \mathrm{~K}$, respectively, indicate that the adsorption of $\mathrm{MB}$ on the chabazite is physical, orderliness-tended, and spontaneous process. Moreover, the synthesized chabazite has a good property of regeneration and reuse. The results indicate that using construction waste to prepare chabazite in application as an adsorbent is feasible, which provides a novel and environment-friendly way for recycling construction waste.
\end{abstract}

\section{Introduction}

In the process of urbanization, building projects have resulted in a large number of construction and demolition waste over the last few decades, and this situation will also exist in the future in order to meet the growing urban population and higher standards of living [1]. Construction waste is generated during the construction, renovation, repair, and demolition of buildings, including concrete, brick, soil, wood, metals, and other residues [2]. Construction waste has already become a serious problem in many countries. The overall utilization of construction waste in developing countries is relatively low. Simple landfill, open-air stacking, and mixing with municipal solid waste are still the main disposal methods of construction waste at this stage, which can cause environment pollution and occupation of land [2-4]. Recycling and reuse of construction waste are mainly used for backfilling of pits and for pavement base and subbase in road engineering. In addition, construction waste can prepare recycled aggregate products, such as recycled aggregate floor tiles and permeable tiles, and prepare recycled concrete and mortar $[5,6]$. Few other technologies of recycling and reuse of construction waste have been studied.

Zeolites are microporous crystalline hydrated aluminosilicates. The basic structural unit is the skeleton of $\mathrm{SiO}_{4}$ and $\mathrm{AlO}_{4}{ }^{-}$tetrahedron formed by elements $\mathrm{Si}, \mathrm{Al}$, and $\mathrm{O}[7,8]$. Because of the good surface chemical properties and pore structure, zeolites have excellent applications in adsorption, separation, catalysis, ion exchange, and filtration [7]. There are many types of zeolites, such as analcime, Na-X, chabazite, and ZSM-5. Zeolites are conventionally synthesized by commercial reagents, but they can also be prepared from industrial by-products or wastes rich in Si and/or $\mathrm{Al}$ [9]. At present, the main industrial wastes used to prepare zeolites are coal fly ash, slag, and biomass ash [10]. Coal fly ash was first used as $\mathrm{Si}$ and $\mathrm{Al}$ sources for zeolite preparation by Höller and Wirsching in 1985 [11]. They prepared zeolite by alkaline activation and studied the effects of activation time, temperature, solution composition, and concentration on the synthesized zeolite. Jin et al. prepared chabazite using 
coal fly ash as low-cost raw materials and obtained the optimal synthesis parameters [12]. Zhang et al. synthesized zeolite $13 \mathrm{X}$ from coal fly ash by the hydrothermal method without adding any extra $\mathrm{Si}$ or $\mathrm{Al}$ sources and measured the $\mathrm{CO}_{2}$ adsorption capacity of the synthesized zeolite $13 \mathrm{X}$ [13]. By contrast, researches on preparing zeolites from biomass ash are relatively less. Kongnoo et al. studied the optimal condition for preparing zeolite $13 \mathrm{X}$ from palm oil mill fly ash, which can be utilized as a Si source, through alkaline fusion and hydrothermal method, and found that the synthesized zeolite $13 \mathrm{X}$ had a better performance in $\mathrm{CO}_{2}$ adsorption than the commercial zeolite 13X [14]. Purnomo et al. used bagasse fly ash as $\mathrm{Si}$ and $\mathrm{Al}$ sources to synthesize highly pure zeolite $\mathrm{Na}-\mathrm{X}$ and $\mathrm{Na}-\mathrm{A}$, which possessed higher porosity and ion exchange capacity than the commercial ones [15].

The premise of using waste to synthesize zeolite is to study the characteristics and synthesis parameters of waste in order to produce pure and stable zeolite, which is suitable for industrial application. After primary analysis, the construction waste used in this study mainly consists of cement blocks, bricks, and a small amount of sand. Based on its composition, it can be utilized as raw material for synthesizing chabazite (a kind of intermediate silica zeolites with $\mathrm{Si} / \mathrm{Al}$ ratio in the range of 2-5) without adding any $\mathrm{Si}$ and $\mathrm{Al}$ sources. Characteristics of the synthesized chabazite were studied and adsorption of methylene blue (MB) was operated to evaluate its adsorption properties as an adsorbent which may be applied in water treatment. This study is aimed at providing a novel and environment-friendly way for recycling and reuse of construction waste and to realize waste control by waste.

\section{Experimental}

2.1. Materials. Construction waste used as raw material was collected from the remnants of rural demolition and relocation around Zhengzhou, China. The main components of construction waste are listed in Table 1 . It can be seen that the main components of construction waste are $\mathrm{CaO}, \mathrm{SiO}_{2}$, and $\mathrm{Al}_{2} \mathrm{O}_{3}$. The content of $\mathrm{CaO}$ is the highest, mainly because the construction waste contains a lot of cement. Moreover, $\mathrm{CaO}$ can provide alkaline environment, which is conducive to the activation of construction waste in the preparation process. $\mathrm{SiO}_{2}$ and $\mathrm{Al}_{2} \mathrm{O}_{3}$ can be silicon and aluminium sources for the preparation of chabazite. The $\mathrm{Si} / \mathrm{Al}$ ratio of the raw material is 2.18 , which is in the range $2-5$ of Si/Al ratio of chabazite. This indicates that using construction waste to synthesize chabazite is feasible according to the composition of raw materials. Thus, the chabazite was synthesized without adding any $\mathrm{Si}$ or $\mathrm{Al}$ sources. The materials were crushed, sieved by 100 -mesh screen, dried at $378 \mathrm{~K}$ for $12 \mathrm{~h}$, and then stored in desiccators. Potassium hydroxide $(\mathrm{NaOH})$ used in the alkaline fusion process is of analytical grade.

2.2. Preparation of Chabazite. In this study, the chabazites were prepared according to alkali fusion hydrothermal synthesis method. Based on our previous experiments, the raw material and the agents were mixed to make a Si/Al ratio of
2 , solid/liquid ratio of 4 , and then calcined in a muffle furnace at $823 \mathrm{~K}$ for $2 \mathrm{~h}$. The obtained substances were ground, added some deionized water, and stirred continuously for 24 hours. Then, the mixtures were poured into hydrothermal synthesis reactors and put in the oven at $363 \mathrm{~K}$ for $24 \mathrm{~h}$ to cay crystallize. After that, the mixtures were washed by deionized water until neutral, then filtered, and finally dried to obtain the chabazite.

2.3. Characterization of the Samples. The chemical composition of construction waste was measured by XRF (XL3t, Thermo Scientific Niton Co., US). The mineral phase of the raw material and the synthesized chabazite were determined by XRD (PANalytical, Holland). The textual characterization of the samples was analyzed by $\mathrm{N}_{2}$ adsorption/desorption isotherms at $77 \mathrm{~K}$ using a Micromeritics ASAP 2000M analyzer. Before testing, the samples were pretreated at $473 \mathrm{~K}$ under vacuum for $4 \mathrm{~h}$. The surface morphology of the samples was analyzed by scanning electron microscopy (Nova Nano 400). Prior to the scanning process, the samples were dried and coated with gold under vacuum to improve electron conductivity.

2.4. Measurement of Adsorption Isotherms and Kinetics. MB was utilized as the model adsorbate. The adsorption isotherm experiments were carried out using doses of $1 \mathrm{~g}$ of samples. $200 \mathrm{~mL}$ different concentrations of $\mathrm{MB}$ solutions with $\mathrm{pH} 6$, namely 50, 100, 200, 300, 400, and $500 \mathrm{mg} \mathrm{L}^{-1}$, were added, mixed with the samples, and mechanically stirred at 150 $\mathrm{rpm}$ for $4 \mathrm{~h}$. The experiments were operated at the temperature of $298 \mathrm{~K}, 308 \mathrm{~K}$, and $318 \mathrm{~K}$, respectively. The adsorbed amount of $\mathrm{MB} q_{e}\left(\mathrm{mgg}^{-1}\right)$ can be obtained using the following equation.

$$
q_{e}=\frac{\left(C_{0}-C_{e}\right) V}{M},
$$

where $C_{0}$ and $C_{e}$ are the initial and the equilibrium concentrations of $\mathrm{MB}$ in solutions $\left(\mathrm{mg} \mathrm{L}^{-1}\right)$, respectively, $V$ is the volume of $\mathrm{MB}$ solution (L), and $M$ is the weight of the adsorbent ( $\mathrm{g})$.

The adsorption kinetic experiments were carried out as follows. A batch of $500 \mathrm{~mL} \mathrm{MB}$ solutions of $300 \mathrm{mg} \mathrm{L}^{-1}$ was mixed with $2.5 \mathrm{~g}$ adsorbents and then stirred at $150 \mathrm{rpm}$. After a certain interval of time, the concentration of MB solution was analyzed. The tests were operated at the temperature of $298 \mathrm{~K}, 308 \mathrm{~K}$, and $318 \mathrm{~K}$, respectively. The adsorbent amount $q_{t}\left(\mathrm{mg} \mathrm{g}^{-1}\right)$ at some time $t$ can be calculated by

$$
q_{t}=\frac{\left(C_{0}-C_{t}\right) V}{M}
$$

where $C_{t}$ represents the concentration of $\mathrm{MB}$ in the aqueous phase at time $t\left(\mathrm{mg} \mathrm{L}^{-1}\right)$.

Additionally, the removal efficiency $(R, \%)$ was also analyzed, which can be calculated by

$$
R=\frac{\left(C_{0}-C_{e}\right)}{C_{0}} \times 100 \% \text {. }
$$


TABLE 1: Chemical composition of construction waste.

\begin{tabular}{lcccccc}
\hline Components & $\mathrm{CaO}$ & $\mathrm{Al}_{2} \mathrm{O}_{3}$ & $\mathrm{SiO}_{2}$ & $\mathrm{MgO}$ & $\mathrm{Fe}_{2} \mathrm{O}_{3}$ & Other \\
\hline Mass percentage (wt\%) & 37.21 & 13.56 & 35.74 & 4.20 & 4.12 & 5.17 \\
\hline
\end{tabular}

2.5. Reusability Procedure. The regeneration experiments were operated to estimate the reusability of the synthesized chabazite. The synthesized sample was added to MB solution $\left(300 \mathrm{mg} \mathrm{L}^{-1}\right)$ with the solid/liquid ratio of $1: 50$ at $298 \mathrm{~K}$ and stirred at $150 \mathrm{rpm}$ for $4 \mathrm{~h}$. After the adsorption process, the MB-loaded chabazite was filtered and collected for regeneration. The sample was calcined in muffle furnace at $823 \mathrm{~K}$ for $1 \mathrm{~h}$ and then cooled down to room temperature for the next cycle.

\section{Results and Discussion}

3.1. Characterization of Materials. Figure 1 shows the appearance of the powders of construction waste and synthesized chabazite. According to Figure 1, construction waste is gray, while the synthesized chabazite is white.

It can be known from Figure 2 that the crystalline phases of the construction waste mainly consist of mullite, quartz, and a few amorphous substances. Among those, mullite, the major component of which is $\mathrm{SiO}_{2}$ and $\mathrm{Al}_{2} \mathrm{O}_{3}$, is a high temperature-resistant silicate mineral with columnar or acicular crystals. The main composition of quartz is $\mathrm{SiO}_{2}$. Though $\mathrm{SiO}_{2}$ and $\mathrm{Al}_{2} \mathrm{O}_{3}$ are abundant in mullite and quartz of the construction waste, their activation is low. Thus, it is necessary to take some measures to destroy the crystalline phase so that aluminium and silicate can be released to activate the construction waste. Usually, alkaline matters, such as $\mathrm{NaOH}$ which was utilized in this study, can be activators. Moreover, $\mathrm{CaO}$ in the raw materials also can provide alkaline environment. The reaction equation of silica and alumina with $\mathrm{NaOH}$ is as follows.

$$
\begin{gathered}
\mathrm{SiO}_{2} 2 \mathrm{NaOH}=\mathrm{Na}_{2} \mathrm{SiO}_{3}+\mathrm{H}_{2} \mathrm{O}, \\
\mathrm{Al}_{2} \mathrm{O}_{3}+2 \mathrm{NaOH}=2 \mathrm{NaAlO}_{2}+\mathrm{H}_{2} \mathrm{O} .
\end{gathered}
$$

Compared with the standard peaks of chabazite (PDF $\# 44-0250)$ and other results in the previous literatures [12, $16,17]$, Figure 2(b) shows the typical characteristic peaks of chabazite. In particular, the significant peaks at around $13^{\circ}$, $22^{\circ}, 30^{\circ}$, and $39^{\circ}$ indicate the specific cage structure comprising a representative zeolite skeleton [18].

The FTIR spectra of construction waste and chabazite samples, which are significantly different, are illustrated in Figure 3. For chabazite, the bands at $3440 \mathrm{~cm}^{-1}$ are related to the vibration of $\mathrm{OH}$-stretching, and the latter is corresponding to the $\mathrm{OH}$-stretching group of $\mathrm{Al}(\mathrm{OH})_{3}$ [19-21]. The peak at 1637 can be assigned to the bending mode of water molecules [17]. The new peak at $1496 \mathrm{~cm}^{-1}$ indicates the asymmetric $\mathrm{Al}-\mathrm{O}$ stretching in the six-coordinate $\mathrm{AlO}_{6}$ group [16]. The strong peak at $991 \mathrm{~cm}^{-1}$ is attribute to the asymmetric $\mathrm{Si}-\mathrm{O}-\mathrm{Si}$ and $\mathrm{Si}-\mathrm{O}-\mathrm{Al}$ stretching vibration or $\mathrm{SiO}_{4}$ tetrahedron stretching vibration in the structure of cha- bazite $[17,22,23]$. The Si-O-Si symmetric stretching vibration and bending vibration in the chabazite cage at $671 \mathrm{~cm}^{-}$ ${ }^{1}$ are a characteristic for chabazite $[16,17]$. The peak at 454 $\mathrm{cm}^{-1}$ is related to the vibration of the double six-membered ring and the $\mathrm{O}-\mathrm{Si}-\mathrm{O}$ bending vibration, suggesting that the pore structure made up of rings in the synthesized chabazite is intact $[22,24]$.

$\mathrm{N}_{2}$ adsorption/desorption curves of construction waste and chabazite at $77 \mathrm{~K}$ are shown in Figure 4 . According to the classification of IUPAC (International Union of Pure and Applied chemistry), the adsorbed curves of construction waste and chabazite belong to type IV. This suggests that the adsorbents are not microporous. Small hysteresis hoops that occur at the relative pressure above 0.2 belong to $\mathrm{H} 3$, which indicates the existence of the mesopore. Moreover, IUPAC classified the pore into three types: micropore with the pore diameter $<2 \mathrm{~nm}$, mesopore with the pore diameter range of $2-50 \mathrm{~nm}$, and macropore with the pore diameter $>50 \mathrm{~nm}$. From Figure 5, it can be seen obviously that the pore sizes of the samples are both larger than $2 \mathrm{~nm}$, manifesting that there are less micropore in construction waste and chabazite. The pores of the synthesized chabazite are mainly concentrated in a diameter of about $4 \mathrm{~nm}$ and $10 \mathrm{~nm}$, and the volume of the corresponding pores is also large.

The pore structure parameters of construction waste and synthesized chabazite are given in Table 2. The results show that the specific surface area of construction waste is just $29.21 \mathrm{~m}^{2} \mathrm{~g}^{-1}$ and the corresponding total pore volume is $0.166 \mathrm{~cm}^{3} \mathrm{~g}^{-1}$ However, the synthesized chabazite has a larger specific surface area of $421.34 \mathrm{~m}^{2} \cdot \mathrm{g}^{-1}$ and a larger total pore volume of $1.391 \mathrm{~cm}^{3} \cdot \mathrm{g}^{-1}$, which are about 20 times and 60 times larger than that of construction waste, respectively. This is consistent with the results obtained from Figures 3 and 4. Ma prepared zeolite $4 \mathrm{~A}$ by coal fly ash, the specific surface area and total pore volume of which were $48.36 \mathrm{~m}^{2} \mathrm{~g}^{-1}$ and $0.0910 \mathrm{~cm}^{3} \mathrm{~g}^{-1}$ [25]. Che et al. prepared three kinds of chabazite with a Si/Al ratio of 2.2 by hydrothermal synthesis, namely $\mathrm{KCHA}, \mathrm{MgCHA}$, and $\mathrm{NH}_{4} \mathrm{CHA}$, the specific surface area of which was $20.2,531.9$, and $76.6 \mathrm{~m}^{2} \mathrm{~g}^{-1}$, respectively [26]. Ghasemi et al. measured the surface area of coal fly ash, and the corresponding synthesized Na-P1 zeolite under optimized condition was 16.32 and $41.52 \mathrm{~m}^{2} \mathrm{~g}^{-1}$ [27]. Meng et al. prepared Na-P zeolite from epidesmine by a hydrothermal method, the BET surface area of which was $17.136 \mathrm{~m}^{2} \mathrm{~g}^{-1}$ and the total pore volume was $0.006845 \mathrm{~cm}^{3} \mathrm{~g}^{-1}$ [28]. Compared with the zeolites mentioned above, the synthesized chabazite in this study has a better textual structure.

\subsection{Adsorption Properties}

3.2.1. Adsorption Isotherms. Adsorption isotherms of $\mathrm{MB}$ on construction waste and synthesized chabazite are illustrated in Figure 6. The adsorbed amount increases rapidly when 


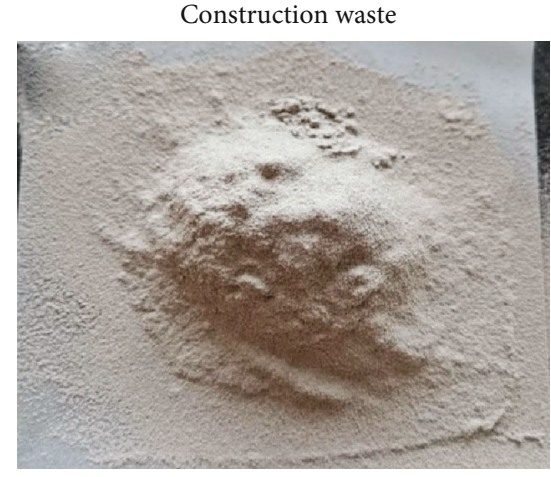

(a)

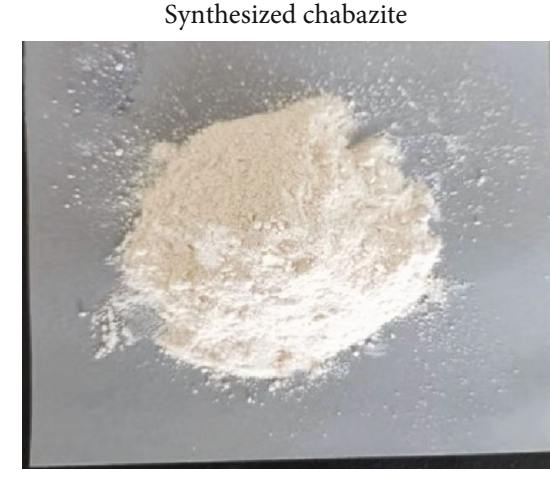

(b)

Figure 1: Pictures of (a) construction waste and (b) synthesized chabazite.

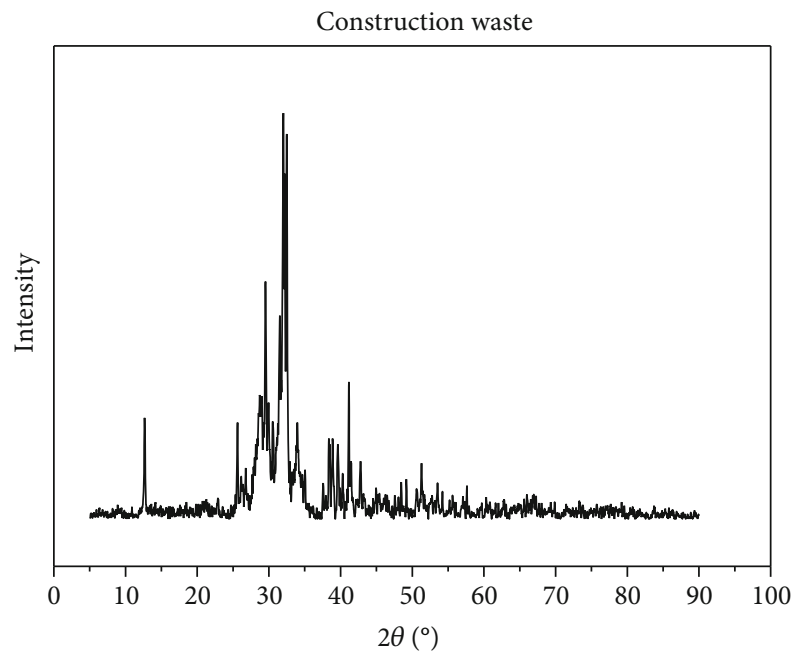

(a)

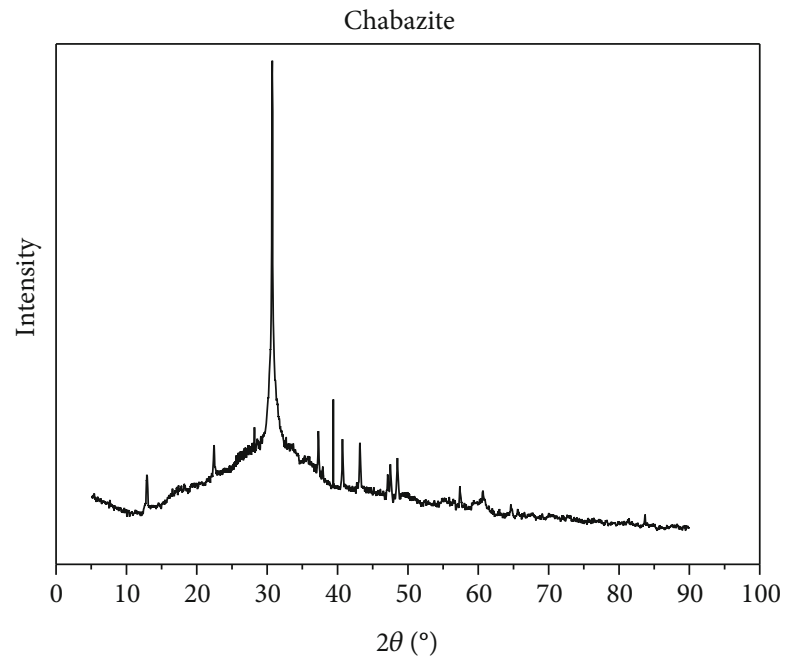

(b)

FIGURE 2: XRD patterns of construction waste and synthesized chabazite.

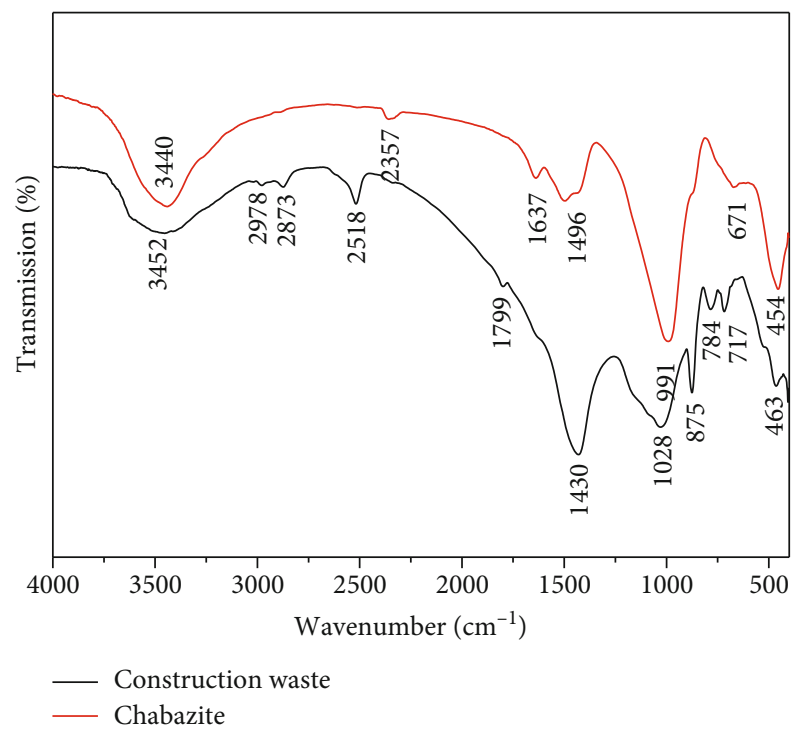

FIGURE 3: FTIR spectra of construction waste and chabazite. the initial concentration of $\mathrm{MB}$ solutions increases at a relative low range. It can be explained that in the beginning, the low adsorbed amount resulted from the limitation of the low MB concentration in the aqueous solution [29]. The increasing adsorbed amount is caused by the increment of adsorption driving force, namely concentration gradient of $\mathrm{MB}$ which can decrease the mass transfer resistance [30, 31]. However, the variation trend of adsorbed amount decreases gradually with the increasing initial concentrations. This is mainly because when the concentration of MB becomes high, the strong adsorption sites are surrounded by more MB ions. As the adsorption is in process, almost all the active sites were occupied, and further increase of $\mathrm{MB}$ concentration will not contribute to the adsorption of more MB ions [29]. Besides, the adsorbed amount on the two samples decreases as temperature becomes higher. This is mostly due to the exothermic nature of the adsorption process. As the temperature increases, the surface adsorption energy and molecular diffusion rate become larger $[32,33]$, and the adsorbed MB molecules become unstable, which reduces the adsorption capacity of the adsorbents. Similar observations have also 


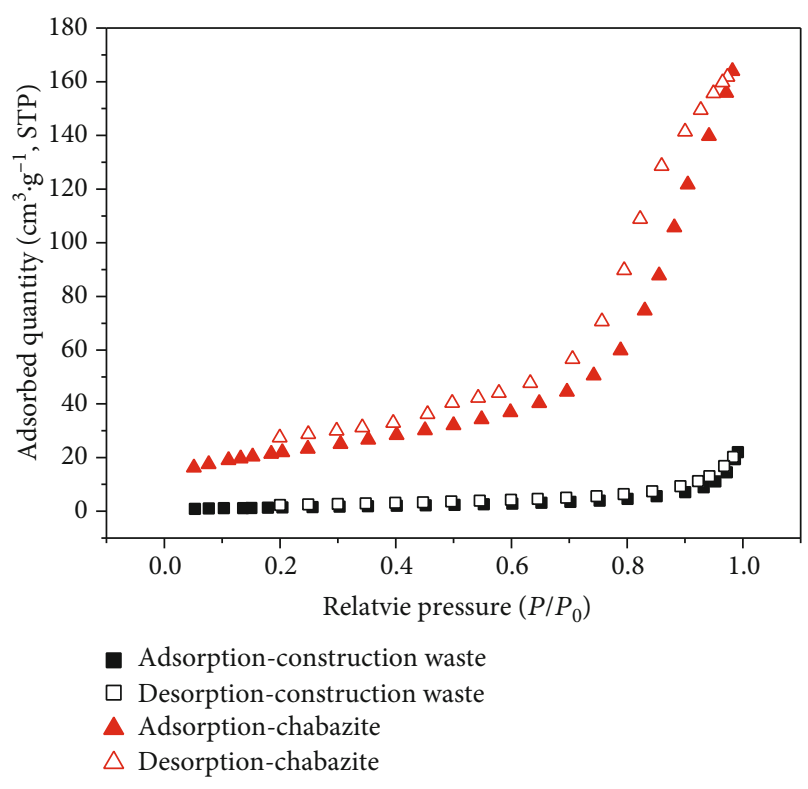

FIGURE 4: $\mathrm{N}_{2}$ adsorption/desorption curves of construction waste and chabazite at $77 \mathrm{~K}$.

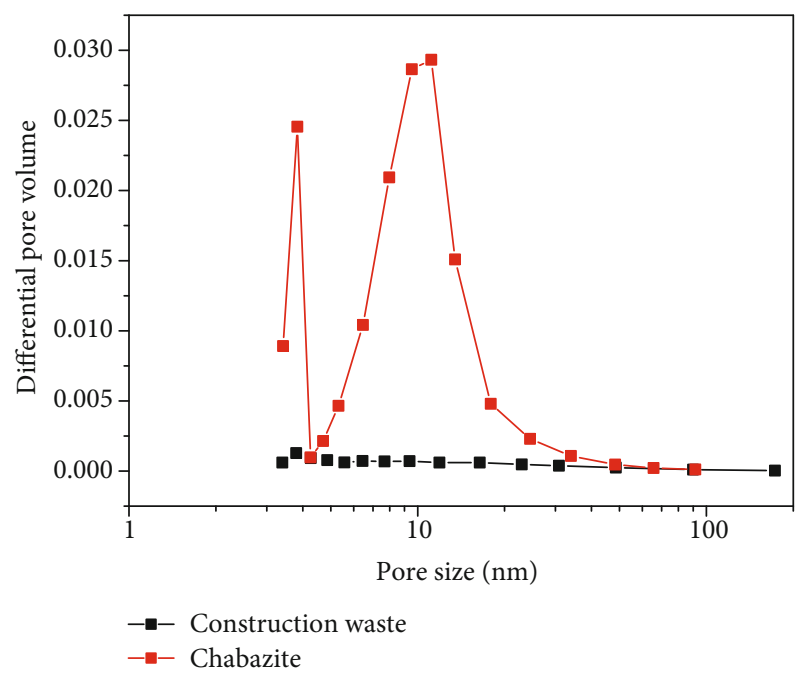

Figure 5: Pore structure distribution of construction waste and chabazite.

been reported for other types of zeolites and adsorbents [29, 34]. It indicates that the higher the temperature, the worse the adsorption. Figure 7 shows the removal of MB on construction waste and synthesized chabazite. It can be seen that the $\mathrm{MB}$ removal rate by chabazite exceeds $80 \%$ at low initial concentration and still goes beyond $65 \%$ at high initial concentration, while that by construction waste is always below $40 \%$. This implies that the synthesized chabazite has an excellent removal effect on MB. Moreover, the removal rate decreases with the initial concentration of $\mathrm{MB}$ increasing, which is due to the limited number of adsorption site.

The study of adsorption isotherms not only has significant effect on understanding the adsorption process and describing adsorption phenomena but also plays a guiding role in applying the adsorbents largely and massively [35, 36]. A variety of adsorption models have been used to describe the adsorption isotherms, such as the Langmuir [37], Freundlich [34], Henry [38], Sips and Toth models [32]. Among these models, the Langmuir and Freundlich models have been utilized widely due to the simplicity.

The Langmuir model is based on the theory that the adsorbate layer adsorbed on the solid surface belongs to a monolayer pattern [39]. The adsorption energy is constant, and there is no interaction among the adsorbate molecules. The equation of this model is presented by

$$
q_{e}=\frac{q_{m} K_{\mathrm{L}} C_{e}}{1+K_{\mathrm{L}} C_{e}}
$$

where $q_{m}$ is the maximum adsorption capacity of adsorbate on the adsorbent $\left(\mathrm{mg} \mathrm{g}^{-1}\right)$ and $K_{\mathrm{L}}$ represents the Langmuir adsorption equilibrium constant $\left(\mathrm{L} \mathrm{mg}^{-1}\right)$.

The Freundlich model, which is an empirical equation, assumes that the adsorption reaction occurs on the heterogeneous surfaces and that the number of sites is nonconstant [40]. The equation of this model can be represented by

$$
q_{e}=K_{\mathrm{F}} C^{\frac{1}{n_{\mathrm{F}}}}
$$

where $K_{\mathrm{F}}\left(\mathrm{mg} \mathrm{g}^{-1}\right)$ and $1 / n_{\mathrm{F}}\left(\mathrm{L} \mathrm{mg}^{-1}\right)$ are the Freundlich characteristic constants, which represent the adsorption capacity and intensity, respectively [41].

Parameters fitted by the Langmuir and Freundlich models at different temperatures on construction waste and synthesized chabazite are displayed in Table 3 .

Comparing the experimental data and the fitted data, it can be concluded that both the Langmuir and Freundlich models can fit well the experimental data of adsorption about $\mathrm{MB}$ on the samples. According to the higher values of $R^{2}$ in Table 3, the Langmuir model described the adsorption isotherms more accurately, which indicates that the samples have a uniform surface and uniformly distributed adsorption sites [42]. Thus, only the Langmuir model fitting lines are illustrated in Figure 6, and the corresponding analysis was operated in the following. Both the adsorption capacity and adsorbed constant of $\mathrm{MB}$ on the adsorbents obtained by the Langmuir model decrease with an increase of temperature, indicating that the adsorption process is exothermic. The maximum adsorption capacity of construction waste at 298 $\mathrm{K}$ is only $8.36 \mathrm{mg} \mathrm{g}^{-1}$, while that of the synthesized chabazite reaches up to $129.18 \mathrm{mg} \mathrm{g}^{-1}$, which is more than 15 times that of construction waste. This is mainly because the specific surface area and pore volume of the synthesized chabazite are much larger than that of the construction waste, which is conductive to the adsorption of MB. The Langmuir constant $K_{\mathrm{L}}$ represents the adsorption affinity related to the binding strength between the adsorbate and adsorbent $[43,44]$. The higher the $K_{\mathrm{L}}$ is, the stronger the adsorption ability of the adsorbent is. Based on Table 3, the Langmuir constant $K_{\mathrm{L}}$ increases with the rising temperature, suggesting the adsorption affinity decreases gradually. In addition, the value of $K_{\mathrm{L}}$ of the synthesized chabazite is larger than that of 
TABLE 2: Pore structure of construction waste and synthesized chabazite.

\begin{tabular}{lccccr}
\hline Sample & $\begin{array}{c}S_{\mathrm{BET}} \\
\left(\mathrm{m}^{2} \mathrm{~g}^{-1}\right)\end{array}$ & $\begin{array}{c}S_{\text {micro }} \\
\left(\mathrm{m}^{2} \mathrm{~g}^{-1}\right)\end{array}$ & $\begin{array}{c}V_{\text {total }} \\
\left(\mathrm{cm}^{3} \mathrm{~g}^{-1}\right)\end{array}$ & $\begin{array}{c}V_{\text {micro }} \\
\left(\mathrm{cm}^{3} \mathrm{~g}^{-1}\right)\end{array}$ & $\begin{array}{c}V_{\text {meso }} \\
\left(\mathrm{cm}^{3} \mathrm{~g}^{-1}\right)\end{array}$ \\
\hline Construction waste & 29.21 & 0 & 0.166 & 0 & 0.161 \\
Chabazite & 421.43 & 4.89 & 1.391 & 0.003 & 0.005 \\
$\left(\mathrm{~cm}^{3} \mathrm{~g}^{-1}\right)$
\end{tabular}

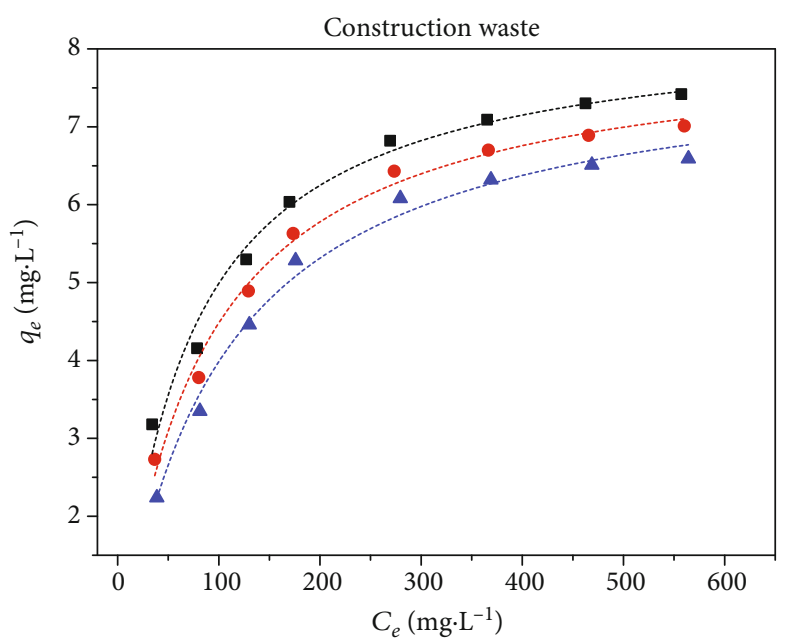

(a)

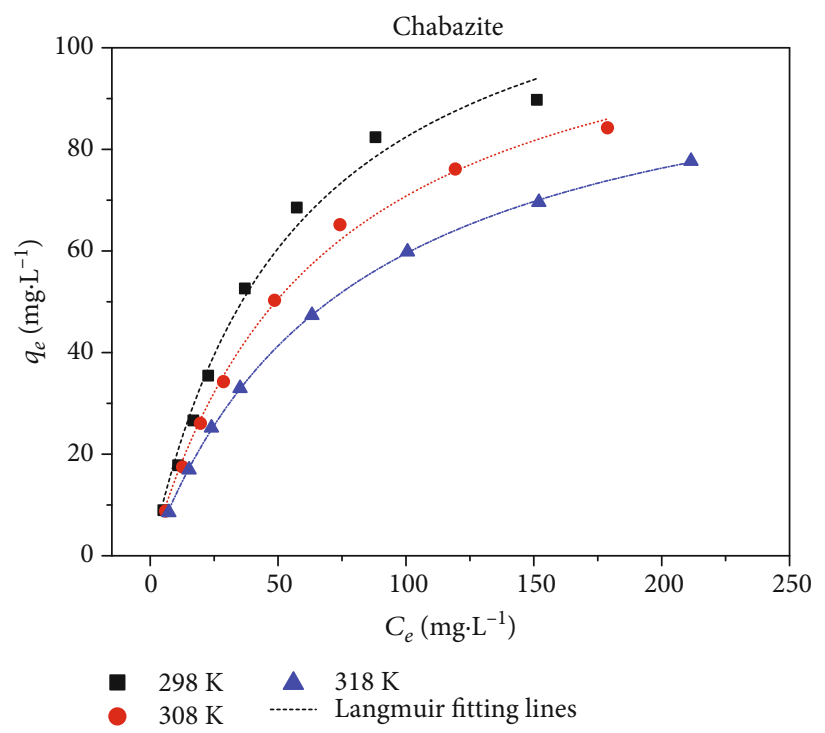

(b)

FIGURE 6: Adsorption isotherms of MB on (a) construction waste and (b) chabazite.

construction waste at the same temperature, indicating the interaction force of $\mathrm{MB}$ with the synthesized chabazite is stronger than that of $\mathrm{MB}$ with construction waste. Previously, some researchers studied the adsorption of $\mathrm{MB}$ on various powder adsorbents, such as zeolite $[45,46]$, coal fly ash [47-49], and carbonaceous adsorbents [50-52]. By comparison of the results obtained in this study with those in the previous literatures in Table 4, it can be concluded that the synthesized chabazite has an excellent adsorption capacity, manifesting the feasibility of preparing chabazite from construction waste.

3.2.2. Adsorption Kinetics. Figure 8 illustrates the variation of $\mathrm{MB}$ solution before and after the adsorption process by construction waste and synthesized chabazite for $1 \mathrm{~h}$ and $3 \mathrm{~h}$, respectively. It can be seen clearly that when the adsorption process was carried out for the same time, the color of $\mathrm{MB}$ solution adsorbed by synthesized chabazite was lighter. That means that the adsorption effect by the synthesized chabazite is better. Besides, the color of $\mathrm{MB}$ solution after adsorption for $1 \mathrm{~h}$ is a little different from that after $3 \mathrm{~h}$, suggesting that the major adsorption occurred in the initial $60 \mathrm{~min}$. Figure 9 depicts the adsorption kinetic curves of $\mathrm{MB}$ on construction waste and synthesized chabazite. It can be seen that the removal rate of $\mathrm{MB}$ reaches more than $90 \%$, and the adsorbed amount is about $35 \mathrm{mg} \mathrm{g}^{-1}$ at $1 \mathrm{~h}$ at $298 \mathrm{~K}$; after that, the adsorption rate and adsorbed amount become slow. This is mainly because at the beginning, the quick adsorption pro- cess is controlled by electrostatic attraction, while in the following stage, the adsorption process is controlled by the van der Waals force [52]. Moreover, the availability of the adsorption sites gradually decreases as the adsorption progresses, so that the adsorbed amount reaches the maximum, namely the adsorption process approaches equilibrium [53].

Adsorption kinetics can reflect the potential controlling steps and the adsorption mechanism, which was necessary for designing a practical adsorption system. In this study, pseudo-first-order kinetic [54], pseudo-second-order kinetic [55], and intraparticle diffusion [29] models were adopted to describe the kinetic data. The corresponding expressions are as follows:

The pseudo-first-order kinetic model is

$q_{t}=q_{e}\left(1-e^{-k_{1} t}\right)$, where $q_{t}$ is the amount of gas adsorbed at time $t\left(\mathrm{mgg}^{-1}\right), t$ is the adsorption time (min), $q_{e}$ is the amount at adsorption equilibrium $\left(\mathrm{mgg}^{-1}\right)$, and $k_{1}$ is the equilibrium rate constant of pseudo-first-order kinetics $\left(\min ^{-1}\right)$.

The pseudo-second-order kinetic model is

$$
\mathrm{q}_{t}=\frac{k_{2} q_{e}{ }^{2}}{1+k_{2} q_{e}},
$$

where $k_{2}$ is the equilibrium rate constant of pseudo-secondorder kinetics, $\mathrm{g} \bullet(\mathrm{mg} \min )^{-1}$. 


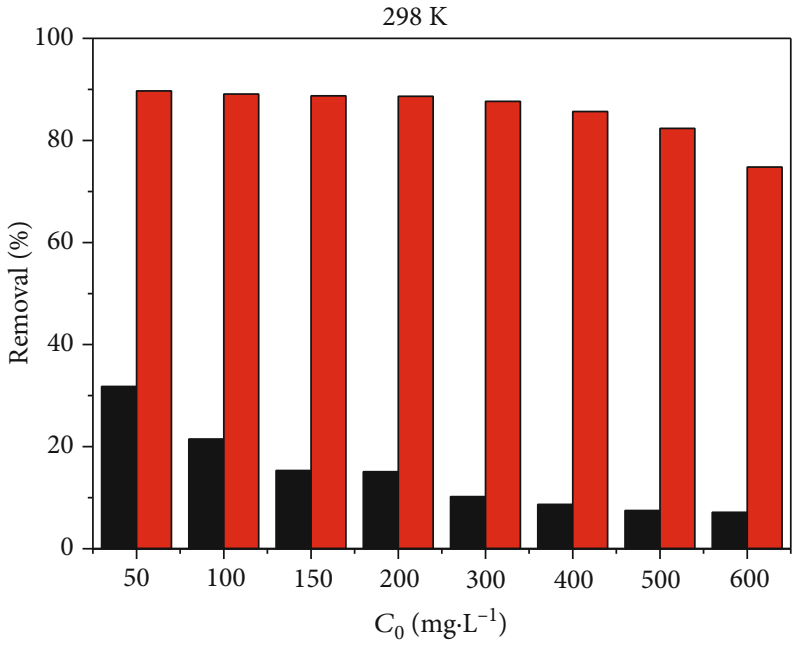

(a)

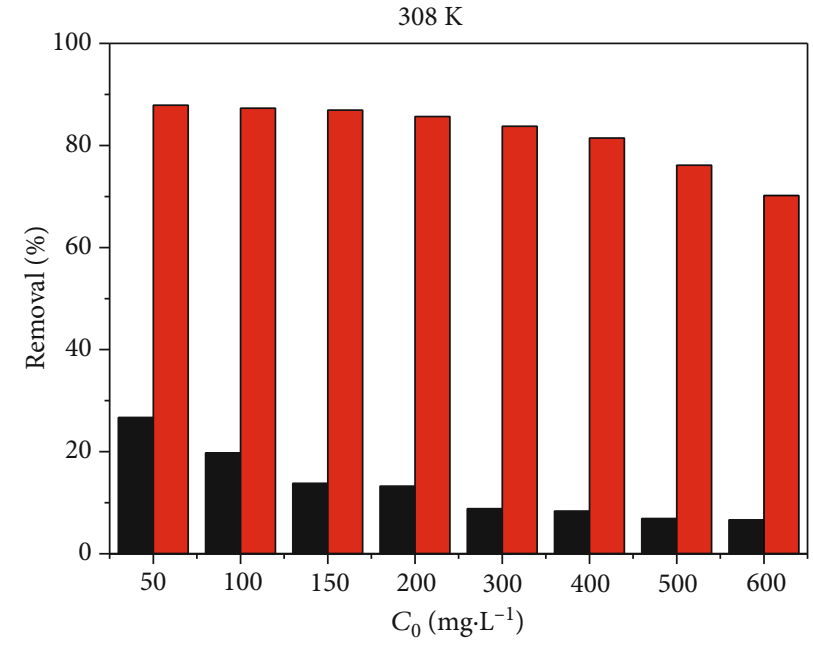

(b)

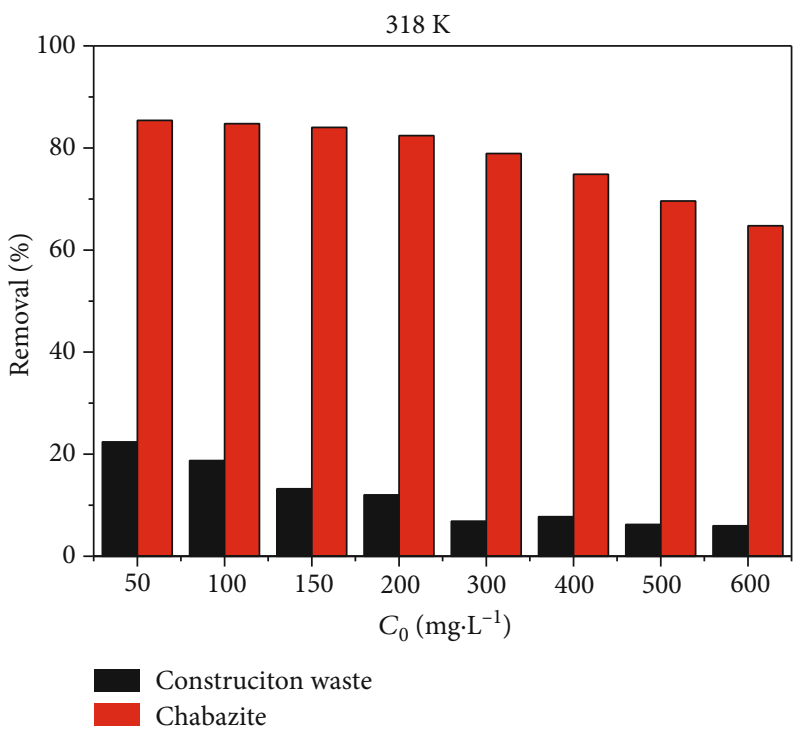

(c)

FiguRE 7: Removal of MB on construction waste and chabazite at different temperatures.

The intraparticle diffusion model is

$$
\mathrm{q}_{t}=k_{3} t^{0.5}+C
$$

where $k_{3}$ is the intraparticle diffusion rate constant, $\mathrm{mg} \bullet(\mathrm{g}$ $\left.\min ^{0.5}\right)^{-1}$, and $C$ is the intercept.

The adsorption kinetic parameters fitted by the three different common models are listed in Table 5.

According to Table 5, the pseudo-second-order kinetic model can describe the adsorption process well for the entire adsorption period with higher values of $R^{2}$ and lower deviation of $q_{e}$ between the experimental data and the calculated data. This suggests that the adsorption of $\mathrm{MB}$ on the synthesized chabazite might depend on the availability of the adsorption sites. Similar phenomena have been reported for $\mathrm{MB}$ adsorption on kaolin and zeolite [56], carbon nanotubes [30], and activated carbon spheres [41]. It indicates that the rate-limiting step may be related to the dye chemisorption [56]. The values of $k_{2}$ and the corresponding $q_{e}$ increase and decrease with the temperature, respectively, suggesting that rising the temperature increases the adsorption rate but reduces adsorption capacity. In addition, based on Figure 9(c), the adsorption of $\mathrm{MB}$ on the synthesized chabazite fitted by the intraparticle diffusion model includes three linear segments [42]. This suggests that there are three ratecontrolling steps in the adsorption process. The first one is the membrane diffusion process, during which the $\mathrm{MB}$ molecules transfer from the solution to the surface of the synthesized chabazite. The second step is the representative of internal particle diffusion. And the third one corresponds to the adsorption equilibrium.

3.2.3. Thermodynamic Parameters. Thermodynamic parameters can represent spontaneity and heat change processes. The thermodynamic parameters enthalpy $(\Delta H)$, entropy 
TABLE 3: Fitting parameters of Langmuir and Freundlich models of MB adsorption isotherms on construction waste and chabazite.

\begin{tabular}{|c|c|c|c|c|c|c|c|}
\hline \multirow[b]{2}{*}{ Sample } & \multirow[b]{2}{*}{ Temperature $(\mathrm{K})$} & \multicolumn{3}{|c|}{ Langmuir } & \multicolumn{3}{|c|}{ Freundlich } \\
\hline & & $\begin{array}{c}q_{m} \\
\left(\mathrm{mgg}^{-1}\right)\end{array}$ & $\begin{array}{c}K_{\mathrm{L}} \\
\left(\mathrm{L} \mathrm{mg}^{-1}\right)\end{array}$ & $R^{2}$ & $\begin{array}{c}K_{\mathrm{F}} \\
\left(\mathrm{mgg}^{-1}\right)\end{array}$ & $\begin{array}{c}n_{\mathrm{F}} \\
\left(\mathrm{L} \mathrm{mg}^{-1}\right)\end{array}$ & $R^{2}$ \\
\hline \multirow{3}{*}{ Construction waste } & 298 & 8.36 & 0.0148 & 0.9796 & 1.29 & 3.5072 & 0.9413 \\
\hline & 308 & 8.13 & 0.0123 & 0.9891 & 1.03 & 3.2031 & 0.9337 \\
\hline & 318 & 7.97 & 0.0100 & 0.9888 & 0.80 & 2.8970 & 0.9165 \\
\hline \multirow{3}{*}{ Chabazite } & 298 & 129.18 & 0.0176 & 0.9971 & 6.93 & 1.8854 & 0.9291 \\
\hline & 308 & 118.13 & 0.0150 & 0.9663 & 5.84 & 1.8890 & 0.9557 \\
\hline & 318 & 106.28 & 0.0127 & 0.9980 & 4.86 & 1.8950 & 0.9747 \\
\hline
\end{tabular}

TABLE 4: Maximum MB adsorption capacity of different powdery adsorbents reported in literature.

\begin{tabular}{|c|c|c|c|}
\hline Adsorbent & $\begin{array}{l}\text { Temperature } \\
(\mathrm{K})\end{array}$ & $\begin{array}{c}q_{e}(\text { Langmuir model }) \\
\left(\mathrm{mg} \mathrm{g}^{-1}\right)\end{array}$ & Reference \\
\hline Ni/Co USY zeolite & 298 & 59.880 & {$[45]$} \\
\hline $\mathrm{Ni} / \mathrm{Co}(\gamma \mathrm{Al}-\mathrm{Si})$ zeolite & 298 & 43.859 & {$[45]$} \\
\hline Acid-treated zeolite & 298 & 2.113 & {$[46]$} \\
\hline Base-treated zeolite & 298 & 1.089 & {$[46]$} \\
\hline Acid-treated coal fly ash & 298 & 8.0 & {$[47]$} \\
\hline Coal fly ash geopolymer & 303 & 38.4 & {$[48]$} \\
\hline Coal fly ash geopolymer & 298 & $50-51.4$ & [49] \\
\hline Carbon nanotubes & 298 & 46.2 & {$[30]$} \\
\hline Acrylic fiber waste-based activated carbon web & 303 & $7.60-9.92$ & {$[50]$} \\
\hline \multirow[t]{2}{*}{ Palm shell waste-based activated carbon } & Room temperature & 218.6 & {$[51]$} \\
\hline & 298 & 129.18 & \\
\hline \multirow[t]{2}{*}{ Chabazite from construction waste } & 308 & 118.13 & This work \\
\hline & 318 & 106.28 & \\
\hline
\end{tabular}

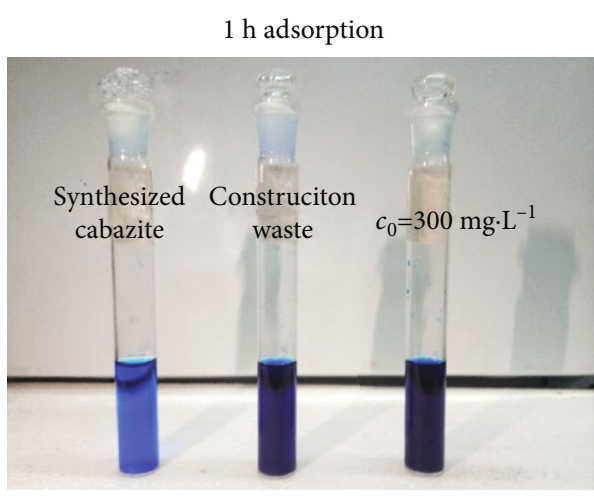

(a)

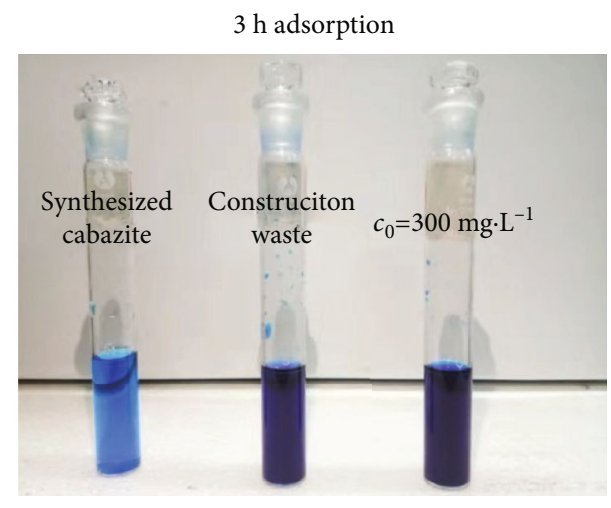

(b)

FIGURE 8: MB solution before and after of the adsorption by construction waste and synthesized chabazite.

$(\Delta S)$, and Gibbs free energy $(\Delta G)$ were calculated as follows $[30,57]$.

$$
\begin{gathered}
\ln K_{L}=\frac{\Delta S}{R}-\frac{\Delta H}{R T}, \\
\Delta G=\Delta H-T \Delta S,
\end{gathered}
$$

where $K_{\mathrm{L}}$ is the Langmuir adsorption equilibrium constant
$\left(\mathrm{L} \mathrm{mol}^{-1}\right), R$ is the gas constant, $\left(8.314 \mathrm{~J} \mathrm{~mol}^{-1} \mathrm{~K}^{-1}\right)$, and $T$ is the solution temperature $(\mathrm{K})$.

A straight line can be drawn by plotting $\ln K_{L}$ against 1 $/ T$, and then, $\Delta H$ and $\Delta S$ can be determined from the slope and the intercept. Thermodynamic parameters at various temperatures are listed in Table 6.

The negative values of $\Delta H$ indicate that the adsorption process on both construction waste and the synthesized chabazite is exothermic. Kara et al. [58] mentioned that the $\Delta H$ 


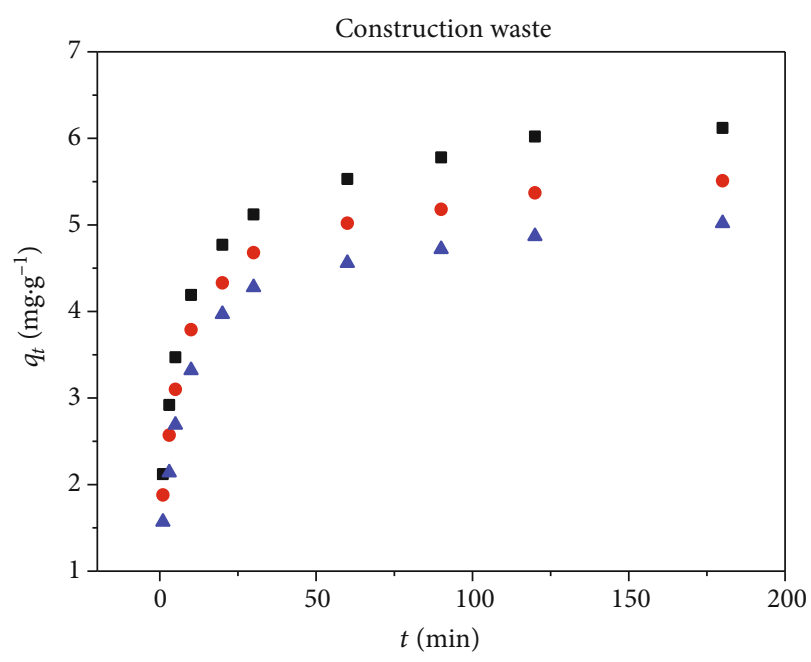

(a)

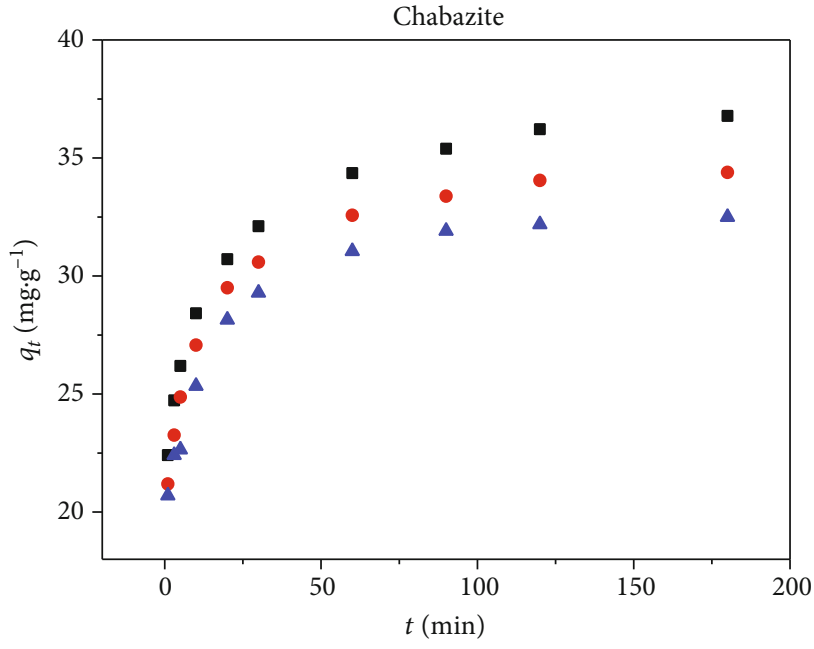

(b)

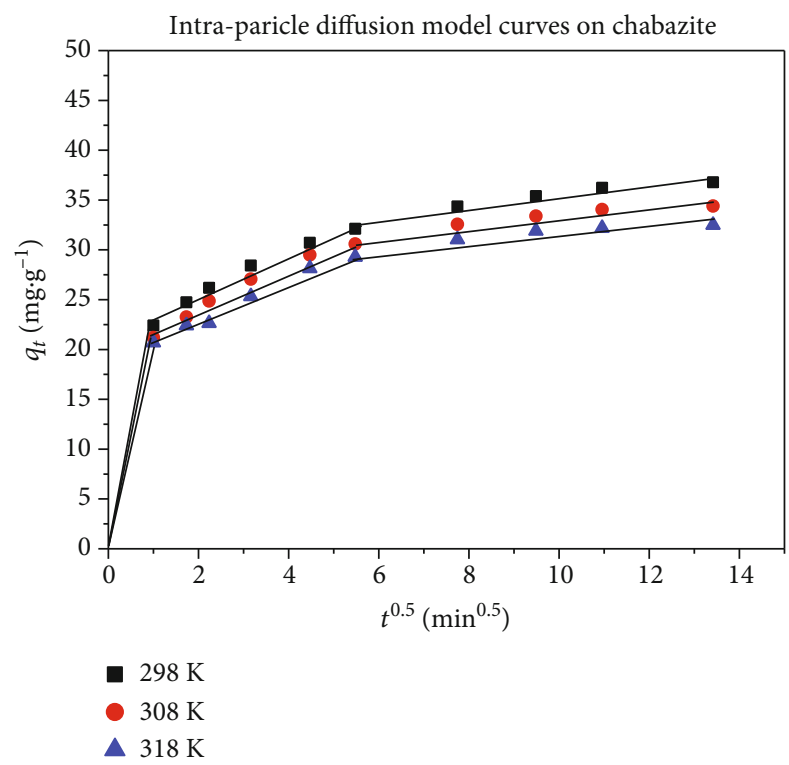

(c)

Figure 9: Adsorption kinetic curves of MB on (a) construction waste and (b) chabazite and (c) intraparticle diffusion model curves on chabazite.

value is lower than $40 \mathrm{~kJ} \mathrm{~mol}^{-1}$ with physisorption. Hence, the results suggest that the adsorption processes of $\mathrm{MB}$ on the adsorbents in this study are the physisorption process. It means that the interaction force between $\mathrm{MB}$ molecular and the surface of the adsorbents may be ascribed to the van der Waals forces and electrostatic attractions [56]. The values of $\Delta S$ are also negative, illustrating a decrease in disorderliness during the adsorption [59]. This is because the molecules of $\mathrm{MB}$ are adsorbed on the adsorbents, reducing the degree of freedom and making the system tend to be orderly [53]. Moreover, the negative values of $\Delta G$ confirm the feasibility of the process and the spontaneous nature of the adsorption. The absolute $\Delta G$ value of $\mathrm{MB}$ on the synthesized chabazite is larger than that on the construction waste, implying that the spontaneity degree of adsorption on the chabazite is higher, namely, the molecules on MB could be adsorbed more easily [53]. Besides, the absolute $\Delta G$ values decrease with the increasing temperature, suggesting that high temperature is not conducive to the adsorption process. This is consistent with the results obtained by adsorption isotherms at different temperatures.

3.3. Regeneration and Reusability. Regeneration is an important aspect for the adsorbent. High-temperature calcination is a useful method to remove MB to regenerate the adsorbent. Seven adsorption-regeneration cycles were operated, and the results are shown in Figure 10. The adsorption capacity is almost constant, with only decreasing by $0.8 \%$ and $1.7 \%$ after the first and seventh regeneration, respectively. This is because most of $\mathrm{MB}$ is oxidized to degrade at high temperature and only few amounts inorganic salt impurities in $\mathrm{MB}$ remain, in which some are difficult to oxidize and degrade 
TABle 5: Parameters of dynamic models of MB on construction waste and chabazite at different temperatures.

\begin{tabular}{|c|c|c|c|c|c|c|c|}
\hline \multirow{2}{*}{ Model } & \multirow{2}{*}{ Parameter } & \multicolumn{3}{|c|}{ Construction waste } & \multicolumn{3}{|c|}{ Chabazite } \\
\hline & & $298 \mathrm{~K}$ & $308 \mathrm{~K}$ & $318 \mathrm{~K}$ & $298 \mathrm{~K}$ & $308 \mathrm{~K}$ & $318 \mathrm{~K}$ \\
\hline \multirow{3}{*}{ Pseudo-first-order kinetic } & $q_{e}\left(\mathrm{mgg}^{-1}\right)$ & 5.51 & 4.98 & 4.57 & 32.23 & 30.54 & 28.79 \\
\hline & $k_{1}\left(\min ^{-1}\right)$ & 0.218 & 0.210 & 0.178 & 0.881 & 0.867 & 0.991 \\
\hline & $R^{2}$ & 0.8063 & 0.8290 & 0.8677 & 0.8583 & 0.8859 & 0.8494 \\
\hline \multirow{3}{*}{ Pseudo-second-order kinetic } & $q_{e}\left(\mathrm{mgg}^{-1}\right)$ & 5.89 & 5.32 & 4.91 & 34.06 & 32.22 & 30.49 \\
\hline & $k_{2}, \mathrm{~g} \bullet(\mathrm{mg} \mathrm{min})^{-1}$ & 0.053 & 0.055 & 0.059 & 0.035 & 0.037 & 0.041 \\
\hline & $R^{2}$ & 0.9387 & 0.9487 & 0.9618 & 0.9402 & 0.9469 & 0.9341 \\
\hline \multirow{3}{*}{ Intraparticle diffusion } & $k_{3}, \mathrm{mg} \bullet\left(\mathrm{g} \min ^{0.5}\right)^{-1}$ & 0.298 & 0.269 & 0.259 & 1.135 & 1.041 & 0.984 \\
\hline & C & 2.826 & 2.539 & 2.170 & 23.956 & 22.873 & 21.749 \\
\hline & $R^{2}$ & 0.8353 & 0.8195 & 0.8113 & 0.894 & 0.8655 & 0.8611 \\
\hline Experimental data & $q_{e}\left(\mathrm{mgg}^{-1}\right)$ & 6.12 & 5.51 & 5.02 & 36.78 & 34.39 & 32.50 \\
\hline
\end{tabular}

TABLE 6: Thermodynamic parameters of MB adsorption on construction waste and chabazite.

\begin{tabular}{|c|c|c|c|c|c|}
\hline \multirow{2}{*}{ Sample } & \multirow{2}{*}{$\Delta H\left(\mathrm{~kJ} \mathrm{~mol}^{-1}\right)$} & \multirow{2}{*}{$\Delta S\left(\mathrm{~J} \mathrm{~mol}^{-1} \mathrm{~K}^{-1}\right)$} & \multicolumn{3}{|c|}{$\Delta G\left(\mathrm{~kJ} \mathrm{~mol}{ }^{-1}\right)$} \\
\hline & & & $298 \mathrm{~K}$ & $308 \mathrm{~K}$ & $318 \mathrm{~K}$ \\
\hline Construction waste & -15.45 & -37.55 & -4.26 & -3.88 & -3.50 \\
\hline Chabazite & -12.83 & -27.37 & -4.68 & -4.40 & -4.13 \\
\hline
\end{tabular}

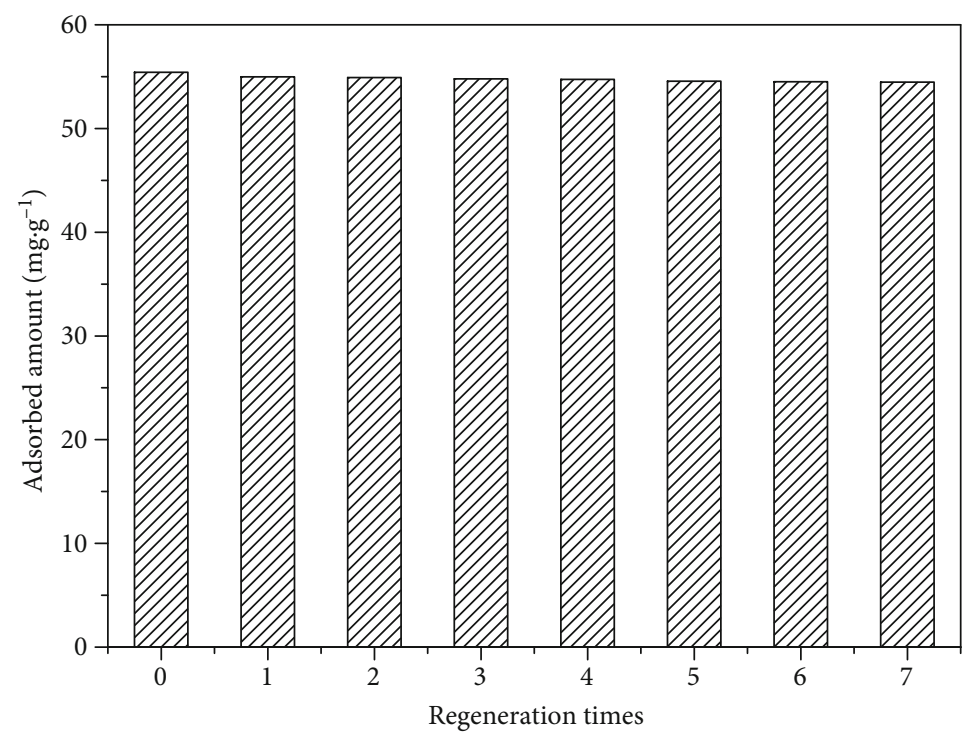

FiguRe 10: Reusability of chabazite for MB removal.

[60]. Thus, the pore structure of the chabazite is recovered and can be reused almost as the initial adsorbent. This method can remove the adsorbed MB and will not cause secondary pollution to the environment.

\section{Conclusion}

Construction waste was utilized as raw material for the preparation of chabazite to apply in water treatment. XRD and FTIR analyses proved the crystalline structure and typical functional groups of synthesized chabazite. According to the results obtained by $\mathrm{N}_{2}$ adsorption/desorption curves at $77 \mathrm{~K}$, the synthesized chabazite has a larger specific surface area of $421.34 \mathrm{~m}^{2} \mathrm{~g}^{-1}$ and a larger total pore volume of $1.391 \mathrm{~cm}^{3} \mathrm{~g}^{-1}$, suggesting that the chabazite has an excellent textual pore structure. Adsorption studies reveal that the maximum adsorption capacity of $\mathrm{MB}$ on the synthesized chabazite is up to $129.18 \mathrm{mg} \mathrm{g}^{-1}$ at $298 \mathrm{~K}$, which is more than 15 times that of construction waste and comparable to that of other powdery adsorbents reported in literature. Furthermore, adsorption kinetic studies show that the major adsorption of $\mathrm{MB}$ occur in the initial $60 \mathrm{~min}$ and can be well 
described by the pseudo-second-order kinetic model. The results of $\Delta H, \Delta S$, and $\Delta G$ indicate that the adsorption of $\mathrm{MB}$ on the synthesized chabazite is physical, orderlinesstended, and spontaneous process. The synthesized chabazite can be easily regenerated and reused. Based on the outcome of this study, it can be concluded that it is feasible for using construction waste to prepare chabazite, which can be used as an adsorbent.

\section{Data Availability}

The data used to support the findings of this study are included within the article.

\section{Conflicts of Interest}

The authors declared no potential conflicts of interest with respect to the research, authorship, and/or publication of this article.

\section{Acknowledgments}

This work was supported by the Henan University of Technology under grant number 2018BS046.

\section{References}

[1] M. Liikanen, K. Grönman, I. Deviatkin et al., "Construction and demolition waste as a raw material for wood polymer composites - assessment of environmental impacts," Journal of Cleaner Production, vol. 225, pp. 716-727, 2019.

[2] H. Duan, J. Wang, and Q. Huang, "Encouraging the environmentally sound management of C\&D waste in China: an integrative review and research agenda," Renewable \& Sustainable Energy Reviews, vol. 43, pp. 611-620, 2015.

[3] S. Jain, S. Singhal, and N. K. Jain, "Construction and demolition waste generation in cities in India: an integrated approach," International Journal of Sustainable Engineering, vol. 12, no. 5, pp. 333-340, 2019.

[4] O. K. M. Ouda, H. P. Peterson, M. Rehan, Y. Sadef, J. M. Alghazo, and A. S. Nizami, "A case study of sustainable construction waste management in Saudi Arabia," Waste and Biomass Valorization, vol. 9, no. 12, pp. 2541-2555, 2018.

[5] D. X. Xuan, L. J. M. Houben, A. A. A. Molenaar et al., "Mixture optimization of cement treated demolition waste with recycled masonry and concrete," Materials and Structures, vol. 45, pp. 143-151, 2011.

[6] J. Yang, Q. Du, and Y. Bao, "Concrete with recycled concrete aggregate and crushed clay bricks," Construction and Building Materials, vol. 25, no. 4, pp. 1935-1945, 2011.

[7] B. Jha and D. N. Singh, "A review on synthesis, characterization and industrial applications of fly ash zeolites," Journal of Materials Education, vol. 33, pp. 65-132, 2011.

[8] A. E. Burakov, E. V. Galunin, I. V. Burakova et al., "Adsorption of heavy metals on conventional and nanostructured materials for wastewater treatment purposes: a review," Ecotoxicology and Environmental Safety, vol. 148, pp. 702-712, 2018.

[9] M. Yoldi, E. G. Fuentes-Ordoñez, S. A. Korili, and A. Gil, “Zeolite synthesis from industrial wastes," Microporous and Mesoporous Materials, vol. 287, pp. 183-191, 2019.
[10] S. S. Bukhari, J. Behin, H. Kazemian, and S. Rohani, "Conversion of coal fly ash to zeolite utilizing microwave and ultrasound energies: a review," Fuel, vol. 140, pp. 250-266, 2015.

[11] H. Höller and U. Wirsching, "Zeolite formation from fly ash," Fortschritte Der Mineralogie, vol. 63, pp. 21-43, 1985.

[12] X. Jin, N. Ji, C. Song, D. Ma, G. Yan, and Q. Liu, "Synthesis of CHA zeolite using low cost coal fly ash," Procedia Engineering, vol. 121, pp. 961-966, 2015.

[13] Z. Zhang, Y. Xiao, B. Wang, Q. Sun, and H. Liu, "Waste is a misplayed resource: synthesis of zeolites from fly ash for $\mathrm{CO}_{2}$ capture," Energy Procedia, vol. 114, pp. 2537-2544, 2017.

[14] A. Kongnoo, S. Tontisirin, P. Worathanakul, and C. Phalakornkule, "Surface characteristics and $\mathrm{CO}_{2}$ adsorption capacities of acid-activated zeolite $13 \mathrm{X}$ prepared from palm oil mill fly ash," Fuel, vol. 193, pp. 385-394, 2017.

[15] C. W. Purnomo, C. Salim, and H. Hinode, "Synthesis of pure $\mathrm{Na}-\mathrm{X}$ and Na-A zeolite from bagasse fly ash," Microporous and Mesoporous Materials, vol. 162, pp. 6-13, 2012.

[16] J. Liang, J. Li, X. Li, K. Liu, L. Wu, and G. Shan, “The sorption behavior of CHA-type zeolite for removing radioactive strontium from aqueous solutions," Separation and Purification Technology, vol. 230, article 115874, 2020.

[17] M. Sakizci and M. Ozer, "The characterization and methane adsorption of Ag-, Cu-, Fe-, and $\mathrm{H}$-exchanged chabazite-rich tuff from Turkey," Environmental Sscience and Pollution Research, vol. 26, no. 16, pp. 16616-16627, 2019.

[18] T. du, X. Fang, Y. Wei, J. Shang, B. Zhang, and L. Liu, "Synthesis of nanocontainer chabazites from fly ash with a Templateand fluoride-free process for cesium ion adsorption," Energy \& Fuels, vol. 31, no. 4, pp. 4301-4307, 2017.

[19] S. S. Metwally and M. F. Attallah, "Impact of surface modification of chabazite on the sorption of iodine and molybdenum radioisotopes from liquid phase," Journal of Molecular Liquids, vol. 290, article 111237, 2019.

[20] G. V. K. Suhas, V. K. Gupta, P. J. M. Carrott, R. Singh, M. Chaudhary, and S. Kushwaha, "Cellulose: a review as natural, modified and activated carbon adsorbent," Bioresource Technology, vol. 216, pp. 1066-1076, 2016.

[21] B. Priya, V. K. Gupta, D. Pathania, and A. S. Singha, "Synthesis, characterization and antibacterial activity of biodegradable starch/PVA composite films reinforced with cellulosic fibre," Carbohydrate Polymers, vol. 109, pp. 171-179, 2014.

[22] H. Gong, W. Liu, L. Liu et al., "In-situ synthesis of an excellent $\mathrm{CO}_{2}$ capture material chabazite," Journal of the Taiwan Institute of Chemical Engineers, vol. 103, pp. 160166, 2019.

[23] S. Korichi, A. Elias, A. Mefti, and A. Bensmaili, "The effect of microwave irradiation and conventional acid activation on the textural properties of smectite: comparative study," Applied Clay Science, vol. 59-60, pp. 76-83, 2012.

[24] H. Aysan, S. Edebali, C. Ozdemir, M. Celik Karakaya, and N. Karakaya, "Use of chabazite, a naturally abundant zeolite, for the investigation of the adsorption kinetics and mechanism of methylene blue dye," Microporous and Mesoporous Materials, vol. 235, pp. 78-86, 2016.

[25] X. Ma, Preparation on a Zeolite from Coal Fly Ash and its Adsorption of $\mathrm{CO}_{2}$ and $\mathrm{CH}_{4}$, Chongqing University, 2017.

[26] S. Che, T. du, Y. L. Song, X. Fang, and Y. S. Wang, "Study on adsorption properties of ammonium exchanged chabazite for $\mathrm{CO}_{2}$," Zeitschrift für Anorganische und Allgemeine Chemie, vol. 645 , no. 11 , pp. 810-816, 2019. 
[27] Z. Ghasemi, I. Sourinejad, H. Kazemian, M. Hadavifar, S. Rohani, and H. Younesi, "Kinetics and thermodynamic studies of Cr (VI) adsorption using environmental friendly multifunctional zeolites synthesized from coal fly ash under mild conditions," Chemical Engineering Communications, vol. 207, no. 6, pp. 808-825, 2020.

[28] X. Meng, X. Guo, Y. Zhong, Y. Pei, N. Chen, and Q. Xie, “Synthesis of a high-quality $\mathrm{NaP}$ zeolite from epidesmine by a hydrothermal method," Bulletin of Materials Science, vol. 42, no. 5, p. 232, 2019.

[29] S. Liu, X. Chen, W. Ai, and C. Wei, "A new method to prepare mesoporous silica from coal gasification fine slag and its application in methylene blue adsorption," Journal of Cleaner Production, vol. 212, pp. 1062-1071, 2019.

[30] Y. Yao, F. Xu, M. Chen, Z. Xu, and Z. Zhu, "Adsorption behavior of methylene blue on carbon nanotubes," Bioresource Technology, vol. 101, no. 9, pp. 3040-3046, 2010.

[31] K. Y. Foo and B. H. Hameed, "Dynamic adsorption behavior of methylene blue onto oil palm shell granular activated carbon prepared by microwave heating," Chemical Engineering Journal, vol. 203, pp. 81-87, 2012.

[32] V. K. Singh and K. E. Anil, "Measurement and analysis of adsorption isotherms of $\mathrm{CO}_{2}$ on activated carbon," Applied Thermal Engineering, vol. 97, pp. 77-86, 2016.

[33] M. S. Shafeeyan, W. M. A. W. Daud, A. Houshmand, and A. Arami-Niya, "Ammonia modification of activated carbon to enhance carbon dioxide adsorption: effect of pre-oxidation," Applied Surface Science, vol. 257, no. 9, pp. 3936-3942, 2011.

[34] N. Tang, C. G. Niu, X. T. Li et al., "Efficient removal of $\mathrm{Cd}^{2+}$ and $\mathrm{Pb}^{2+}$ from aqueous solution with amino- and thiolfunctionalized activated carbon: isotherm and kinetics modeling," Science of the Total Environment, vol. 635, pp. 13311344, 2018.

[35] K. Y. Foo and B. H. Hameed, "Insights into the modeling of adsorption isotherm systems," Chemical Engineering Journal, vol. 156, no. 1, pp. 2-10, 2010.

[36] V. K. Gupta, I. Ali, T. A. Saleh, M. N. Siddiqui, and S. Agarwal, "Chromium removal from water by activated carbon developed from waste rubber tires," Environmental Science Pollution and Research, vol. 20, no. 3, pp. 1261-1268, 2013.

[37] S. Mostafavl, V. Rezaverdinejad, and S. Pirsa, "Design and fabrication of nanocomposite-based polyurethane filter for improving municipal waste water quality and removing organic pollutants," Adsorption Science \& Technology, vol. 37, no. 1-2, pp. 95-112, 2019.

[38] H. Yi, F. Li, P. Ning et al., "Adsorption separation of $\mathrm{CO}_{2}, \mathrm{CH}_{4}$, and $\mathrm{N}_{2}$ on microwave activated carbon," Chemical Engineering Journal, vol. 215-216, pp. 635-642, 2013.

[39] B. Li, L. Yang, C. Q. Wang et al., "Adsorption of Cd(II) from aqueous solutions by rape straw biochar derived from different modification processes," Chemosphere, vol. 175, pp. 332-340, 2017.

[40] J. J. Lee and J. K. Jeon, "Isotherm, kineti and thermodynamic studies on adsorption of bromocresol purple acid red 66 and acid blue 40 using activated carbon," Journal of Nanoscience and Nanotechnology, vol. 21, pp. 4104-4109, 2021.

[41] Z. G. Jia, Z. Y. Li, S. B. Li, Y. Li, and R. Zhu, “Adsorption performance and mechanism of methylene blue on chemically activated carbon spheres derived from hydrothermallyprepared poly(vinyl alcohol) microspheres," Journal of Molecular Liquids, vol. 220, pp. 56-62, 2016.
[42] X. Cai, J. Li, Y. Liu et al., "Design and preparation of chitosancrosslinked bismuth ferrite/biochar coupled magnetic material for methylene blue removal," International Journal of Environmental Research and Pulic Health, vol. 17, p. 6, 2020.

[43] C. Yang, L. Yu, R. Chen, J. Cheng, Y. Chen, and Y. Hu, "Congo red adsorption on metal-organic frameworks, MIL-101 and ZIF-8: kinetics, isotherm and thermodynamic studies," Desalination and Water Treatment, vol. 94, pp. 211-221, 2017.

[44] C. Fan, K. Li, J. Li, D. Ying, Y. Wang, and J. Jia, "Comparative and competitive adsorption of $\mathrm{Pb}$ (II) and $\mathrm{Cu}$ (II) using tetraethylenepentamine modified chitosan/ $\mathrm{CoFe}_{2} \mathrm{O}_{4}$ particles," Journal of Hazardous Materials, vol. 326, pp. 211-220, 2016.

[45] S. Oukil, F. Bali, and D. Halliche, "Adsorption and kinetic studies of methylene blue on modified HUSY zeolite and an amorphous mixture of $\gamma$-alumina and silica," Separation Science and Technology, vol. 55, no. 15, pp. 2642-2658, 2020.

[46] K. Y. Hor, J. M. C. Chee, M. N. Chong et al., "Evaluation of physicochemical methods in enhancing the adsorption performance of natural zeolite as low-cost adsorbent of methylene blue dye from wastewater," Journal of Cleaner Production, vol. 118, pp. 197-209, 2016.

[47] S. Wang, Y. Boyjoo, and A. Choueib, "A comparative study of dye removal using fly ash treated by different methods," Chemosphere, vol. 60, no. 10, pp. 1401-1407, 2005.

[48] L. Li, S. Wang, and Z. Zhu, "Geopolymeric adsorbents from fly ash for dye removal from aqueous solution," Journal of Colloid and Interface Science, vol. 300, no. 1, pp. 52-59, 2006.

[49] L. Yi, C. Yan, Z. Zhang, Y. Gong, H. Wang, and X. Qiu, “A facile method for preparation of floatable and permeable fly ashbased geopolymer block," Materials Letters, vol. 185, pp. 370$373,2016$.

[50] S. Naeem, V. Baheti, J. Wiener, and J. Marek, "Removal of methylene blue from aqueous media using activated carbon web," The Journal of The Textile Institute, vol. 108, pp. 803$811,2016$.

[51] K. T. Wong, N. C. Eu, S. Ibrahim, H. Kim, Y. Yoon, and M. Jang, "Recyclable magnetite-loaded palm shell-waste based activated carbon for the effective removal of methylene blue from aqueous solution," Journal of Cleaner Production, vol. 115, pp. 337-342, 2016.

[52] R. Han, P. Han, Z. Cai, Z. Zhao, and M. Tang, "Kinetics and isotherms of neutral red adsorption on peanut husk," Journal of Environmental Science, vol. 20, no. 9, pp. 1035-1041, 2008.

[53] X. Song, L.'. Wang, X. Ma, and Y. Zeng, “Adsorption equilibrium and thermodynamics of $\mathrm{CO}_{2}$ and $\mathrm{CH}_{4}$ on carbon molecular sieves," Applied Surface Science, vol. 396, pp. 870-878, 2017.

[54] X. Fan, R. Gan, J. Liu et al., "Adsorption and desorption behaviors of antibiotics by tire wear particles and polyethylene microplastics with or without aging processes," The Science of the Total Environment, vol. 771, article 145451, 2021.

[55] A. Khalil, N. Sergeevich, and V. Borisova, "Removal of ammonium from fish farms by biochar obtained from rice straw: isotherm and kinetic studies for ammonium adsorption," Adsorption Science \& Technology, vol. 36, no. 5-6, pp. 12941309, 2018.

[56] K. Rida, S. Bouraoui, and S. Hadnine, "Adsorption of methylene blue from aqueous solution by kaolin and zeolite," Applied Clay Science, vol. 83-84, pp. 99-105, 2013.

[57] J. Abdulsalam, J. Mulopo, S. O. Bada, and B. Oboirien, "Equilibria and Isosteric Heat of Adsorption of Methane on 
Activated Carbons Derived from South African Coal Discards,” ACS Omega, vol. 5, pp. 32520-32539, 2020.

[58] M. Kara, H. Yuzer, E. Sabah, and M. S. Celik, "Adsorption of cobalt from aqueous solutions onto sepiolite," Water Research, vol. 37, no. 1, pp. 224-232, 2003.

[59] V. K. Gupta, N. Atar, M. L. Yola, Z. Üstündağ, and L. Uzun, “A novel magnetic [email protected] core-shell nanoparticles anchored graphene oxide recyclable nanocatalyst for the reduction of nitrophenol compounds," Water Research, vol. 48, pp. 210-217, 2014.

[60] Q. Qin, Study on Adsorption and High Gas-Stream Oxidation in the Treatment of Dye Wastewater, Guangxi Normal University, 2008. 